\title{
Diet supplement effect based on cottonseed meal and Vitellaria paradoxa leaves on Borgou cows performance in rainy season
}

\author{
Roukayath CHABI TOKO ${ }^{1}$, Mahamadou DAHOUDA ${ }^{1}$, Fernand GBAGUIDI ${ }^{2 *}$ and \\ Soumanou SEIBOU TOLEBA ${ }^{1}$ \\ ${ }^{1}$ Département de Production Animale FSA/UAC, 01 BP 526 Cotonou, Bénin. \\ ${ }^{2}$ Laboratoire National de Pharmacognosie/ Centre Béninois de la Recherche Scientifique et \\ Technique (CBRST), 01BP 06 Oganla, Porto-Novo, Benin. \\ *Corresponding author; E-mail: ahokannou@yahoo.fr
}

\begin{abstract}
An experiment was carried out to investigate the effect of supplementing lactating cows with cottonseed meal and Vitellaria paradoxa leaves in the rainy season on milk yield and content, cows daily weight gain and profitability. The experimental design was $3 \times 3$ Latin square with 5 repetitions. Fifteen Borgou cows were offered three diets: grazing on natural pasture, grazing on pasture plus $1.5 \mathrm{~kg}$ of cottonseed meal supplement and grazing on natural pasture plus $500 \mathrm{~g}$ of Vitellaria paradoxa leaves. Daily milk yield was $946.58 \mathrm{~g}$, $1690.07 \mathrm{~g}$ and $1176.89 \mathrm{~g}$ for the control, cottonseed meal and Vitellaria paradoxa leaves group respectively. Cows supplemented with cottonseed meal produce significantly $(\mathrm{p}<0.05)$ more milk than the others. The mean values were $15.12 \%, 0.35 \%, 5.92 \%$ and $4.13 \%$ respectively for total solid, ash, fat and protein content. Vitellaria paradoxa leaves significantly $(\mathrm{p}<0.05)$ increase total solid level and ash as well as ash with cottonseed meal. Furthermore, calves daily weight gain (DWG) was significantly different. A net return analysis shows that cottonseed meal and Vitellaria paradoxa leaves supplementation in rainy season was profitable even if Vitellaria paradoxa leaves were more beneficial.
\end{abstract}

(C) 2010 International Formulae Group. All rights reserved.

Keywords: Borgou cows, dairy production, live weight changes, net return, supplements.

\section{INTRODUCTION}

Indigenous cows, which are generally low milk producers, are the major sources of milk in Africa. This low production is related to extensive traditional management where milk production is very low and does not satisfy the needs for a population in growth (Faye and Alary, 2001). Dairy production in Benin relies on native cattle breeds, among which the Borgou cattle. This breed accounts for $51 \%$ of Benin's cattle population (MAEP, 2007) and its production system is a traditional low input system involving extensive grazing on natural pasture without supplementation. However, Borgou cows have the highest daily milk yield compared to the other local breeds (Ogodja, 1988; Chabi Maco, 1992). Nevertheless, for milk consumed in Benin, 60\% is imported (FAO, 2009) because the local production remains insufficient (37.000 tonnes in 2007). It is therefore necessary to increase local breed dairy productivity, essentially through animal nutrition because according to Harris et al. 
(1994), proper mineral nutrition and supplementation is essential to animal health and high level of milk production. Some research activities are then made but most of the time in dry season to access supplements benefit on milk production (Kané, 1996; Senou et al., 2008). Recent research in Borgou cows dairy production are scarce (Idrissou, 2004; Senou et al., 2008) and only one (Senou et al., 2008) put interest in supplements effect on milk yield. This study will therefore provide data on supplementation effect on milk yield, chemical composition of milk, daily weight gain and its economic implications and also supplements need in wet season.

The aim of the present investigation was therefore to evaluate the effect of cottonseed meal and Vitellaria paradoxa leaves supplementation on milk yield, milk content, daily weight gain and the economic implications of rainy season's supplementation.

\section{MATERIALS AND METHODS}

The experiment was conducted at Okpara State farm located in Borgou department, between latitude $9^{\circ} 6^{\prime}-9^{\circ} 21^{\prime} \mathrm{N}$ and longitude $2^{\circ} 39^{\prime} \mathrm{E}$ in 2005 , during rainy season (from 24/07/2005 to 01/10/2005). This region is characterized by a continental Sudanian climate with a dry season from November to April and a rainy season from May to October. The average rainfall is $1119.41 \mathrm{~mm} /$ year in Okpara State farm and the mean annual temperature ranges between $25.3{ }^{\circ} \mathrm{C}$ to $30.5^{\circ} \mathrm{C}$. The vegetation consists of wooded or shrubby savannas and old fallows overgrown by various graminaceous formations.

Fifteen Borgou cows were selected from Opkara State farm herd according to parity number and animals' age .The lactating cows were on average in their third stage of lactation (205 days) at the onset of the experiment and weighed on average 225.2 (control), 225.4 (control + cottonseed meal) and 215.8 (control + Vitellaria paradoxa leaves) $\mathrm{kg}$. The experiment lasted ten weeks preceded by a two week adaptation phase (2407-05 to 01-10-05). Animals were allotted in $3 \times 3$ Latin square design with five repetitions. The cows were allotted randomly to three treatment groups corresponding to three feeding systems and numbers in each group were similar to the number of lactation $(2,3,4$ and 6). Cows for the first feeding system were subjected to 6 hours (from 11 a.m. to 5 p.m.) grazing on natural pasture predominantly composed of Andropogon gayanus, Hyparrhenia involucrata, Pennisetum polystachion, Setaria sphacelata, Brachiaria ruziziensis and Stylosanthes hamata. Animals in the second and third treatment were respectively supplemented with $1.5 \mathrm{~kg}$ of cottonseed meal and $500 \mathrm{~g}$ of Vittelaria leaves (according to breeders, Vitellaria leaves have milk stimuli properties but its quantity feed is low) after the six hours gazing on natural pasture. Mineral blocs and water were available ad libitum.

The cows were hand milked twice a day (7:00 a.m. and at 18:00 p.m). Calves were allowed to suck for about one minute in order to stimulate let down of the milk. The milk yield (in kilograms) of each cow was recorded using a scale with $25 \mathrm{~g}$ precision. Milk samples were collected in the morning and afternoon milking each week and stored at $0{ }^{\circ} \mathrm{C}$ without addition of preservative and used for chemical analysis. These samples were analyzed for total protein using Kjeldahl method. Butterfat was determined by the Gerber method and total solids by evaporation (103 ${ }^{\circ} \mathrm{C}$ for 3 hours) using the procedures described by AOAC (1996).

The cost of the supplementary feeds consumed by the animals throughout the feeding trial was computed for each cow. Feed costs at the prevailing market prices in 2005, as well as milk price are considered in order to quantify the net benefits from the feeding intervention.

Cottonseed meal and Vitellaria paradoxa leaves samples collected each week were analysed for dry matter, crude protein, ash and crude fibre according to AOAC (1996) methods. 
Cows and calves were weighed at the beginning and the end of experimental period, after morning milking (using a scale of $1 \mathrm{~kg}$ of precision).

The data were analyzed according to general linear model procedure (GLM) of SAS package (SAS, 1989), then, the least square means were estimated and compared by the Student test.

\section{RESULTS AND DISCUSSION Milk production and composition}

The proximate composition of the supplemental diets is presented in Table 1 . The crude protein contents and crude fibre of cottonseed meal is better than in Vittelaria paradoxa leaves. Addition of supplements appears to improve the nutritive quality of diet.

Supplementation has an impact on milk production. But only cottonseed meal supplementation significantly $\quad(\mathrm{p}<0.05)$ increased milk yield (with $78.54 \%$ increase compared to the control) (Table 2). The better milk yield of supplemented cows was obviously a response of the animals to extra nutrients (especially protein) consumed by them unlike the non-supplemented cows that depended solely on forages available on pasture. The increase in milk yield using cottonseed meal due to its protein value is higher than that obtained by Ogodja and Hounsou-Ve (1992) when supplementing Borgou cows with whole cottonseed. These results are probably related to genetic selection that improved the Okpara State farm cows' milk yield and to a better sanitary control. But milk yield recorded by Senou et al. (2008) when supplementing the same breed with cottonseed meal is higher (2 liters). This difference on the milk yield could be due to the quantity supplemented $(2 \mathrm{~kg})$ which will provide more protein to cows' diet.

Milk content increased with supplement use. There was a significant increase $(\mathrm{P}<0.05)$ in milk total solid with Vitellaria paradoxa leaves supplementation as well as in milk ash with cottonseed meal supplementation. But crude protein and butterfat levels were not significantly (P>0.05) affected by diet composition (Table 2 ). The differences of milk constituents are largely due to the variations in the milk yield which, in this study, must have been affected by differences in the composition of supplements fed to the cows. Milk content recorded is higher than that obtained by Yilma et al. (2006) with Boran cattle essentially due to genetic differences.

\section{Daily weight gain}

Cows and calves live weight and cows daily weight gain were similar among the treatment. A significant increase of calves daily weight gain (DWG3) belongs to cows supplemented cottonseed meal was observed. This could be explained by the quantity of milk consumed by these calves, which is probably higher than that of cows unsupplemented.

Vittelaria paradoxa leaves group calves' daily weight gain from birth to the beginning of the experimental period is significantly higher than the others. The difference in calves daily weight gain could be due to variations in quantity of milk leave to calves before experiment beginning and herd. Calves belong to cows supplemented Vitellaria paradoxa leaves significantly increase their daily weight gain (DWG 1 and DWG2) (Table 3). This result shows that Vittelaria paradoxa leaves induce more body weight increase than milk yield.

Daily weight gain obtained for calves belonging to cows non-supplemented and those supplemented cottonseed meal are similar to those recorded by Ogodja and Hounsou-Ve (1992) with $1 \mathrm{~kg}$ of whole cottonseed supplementation in traditional management systems. But Youssao et al. (2009) obtained Borgou calves' live weight at birth and daily weight gain higher values. It is probably due to phenotypic selection of calves which induce increase in weight performances and on genetic variability among calves.

\section{Cost-benefit analysis}

The cost-benefit ratio was used to evaluate the profitability of supplementing Borgou cows during rainy season. Considering the cost of feed (100 F CFA the kilogram) and the market price of milk (300 F CFA the litre) in 2005 in the locality, Vitellaria paradoxa leaves supplementation 
appears to be more profitable than cottonseed meal supplementation (Table 4). The benefit: cost ratio is superior to 1 , showing that dairy production is globally a profitable activity. However, Vitellaria paradoxa leaves treatment shows a higher profitability (Table 4). But cottonseed meal treatment group profitability is lower than unsupplemented treatment group. This is due to cottonseed meal high cost which weighed down the feed cost and to the fact that milk yield obtain is not high enough. For better profitability, it can be recommended to use supplement with higher concentration as cottonseed meal at early lactation and change with tropical legumes grasses available locally with higher protein content or their seeds at late lactation. So to substantially improve breeders' incomes, local feed resources valorisation such as tropical legumes and concentrate better management is necessary.

Table 1: Composition of supplements diets ( $\%$ of dry matter).

\begin{tabular}{lcccc}
\hline Supplements & Dry matter & Ash & Crude protein & Crude fibre \\
\hline Vittelaria leaves & 47,63 & 5,77 & 14,50 & 17,2 \\
Cottonseed meal & 87,30 & 6,35 & 34,78 & 26,5 \\
\hline
\end{tabular}

Table 2: Effect of cottonseed meal and Vitellaria paradoxa leaves supplementation on milk yield and milk composition.

\begin{tabular}{lccccc}
\hline Treatment & Milk yield $(\mathbf{g})$ & \multicolumn{4}{c}{ Milk composition (\%) } \\
\cline { 3 - 6 } & & Total solids & Ash & $\begin{array}{c}\text { Crude } \\
\text { protein }\end{array}$ & Butterfat \\
\hline Control & $946.58 \mathrm{a}$ & $14.42 \mathrm{a}$ & $0.23 \mathrm{a}$ & $3.86 \mathrm{a}$ & $5.92 \mathrm{a}$ \\
$\mathrm{CSM}$ & $1690.07 \mathrm{~b}$ & $14.35 \mathrm{a}$ & $0.55 \mathrm{~b}$ & $4.29 \mathrm{a}$ & $5.62 \mathrm{a}$ \\
VPL & $1176.89 \mathrm{a}$ & $16.60 \mathrm{~b}$ & $0.25 \mathrm{a}$ & $4.25 \mathrm{a}$ & $6.22 \mathrm{a}$ \\
SE & 217.54 & 0.67 & 0.04 & 0.17 & 0.31 \\
\hline \multicolumn{4}{l}{ Means in the same column followed by different letters are significantly different $(\mathrm{p}<0,05)$} \\
\end{tabular}

Table 3: Cows and calves live weight (kg) and daily weight gain (DWG) (g/d).

\begin{tabular}{llcccc}
\hline Age & Variables & Control & $\begin{array}{c}\text { Cottonseed } \\
\text { meal }\end{array}$ & $\begin{array}{c}\text { Vitellaria } \\
\text { paradoxa } \text { leaves }\end{array}$ & RSD \\
\hline \multirow{3}{*}{ Cows } & LW1 $(\mathrm{kg})$ & 218.4 & 237.8 & 215.6 & 29.42 \\
& LW2 $(\mathrm{kg})$ & 221.2 & 242.6 & 226.4 & 30.21 \\
& DWG $(\mathrm{g} / \mathrm{d})$ & 50 & 85.7 & 192.84 & 112.97 \\
\hline \multirow{4}{*}{ Calves } & LW3 $(\mathrm{kg})$ & 17.7 & 17 & 17.8 & 0.65 \\
& LW4 $(\mathrm{kg})$ & 61.4 & 71.2 & 70.2 & 11.21 \\
& LW5 $(\mathrm{kg})$ & 64.4 & 78.2 & 74.2 & 11.29 \\
& DWG1 $(\mathrm{g} / \mathrm{d})$ & $186.06 \mathrm{a}$ & $231.98 \mathrm{ab}$ & $260.23 \mathrm{~b}$ & 41.68 \\
& DWG 2 (g/d) & $161.1 \mathrm{a}$ & $212.06 \mathrm{~b}$ & $219.1 \mathrm{~b}$ & 34.52 \\
& DWG3 (g/d) & $53.54 \mathrm{a}$ & $124.98 \mathrm{~b}$ & $71.42 \mathrm{ab}$ & 39.57 \\
\hline
\end{tabular}

Means in the same column followed by different letters are significantly different $(\mathrm{p}<0,05)$

LW1 : Cows live weight at the beginning of the experimental period; LW2: Cows live weight at the end of the experimental period; DWG: Cows daily weight gain from the beginning to the end of the experimental period; LW3: Calves live weight at birth; LW4: Calves live weight at the beginning of experimental period; LW5: Calves live weight at the end of experimental period; DWG1: Calves daily weight gain from birth to the beginning of the experimental period; DWG2: Calves daily weight gain from birth to the end of the experimental period; DWG3: Calves daily weight gain from the beginning to the end of the experimental period; RSD: Residual Standard Deviation. 
Table 4: Effect of supplements on the profitability: cost ratio and benefit (FCFA)/litre of milk sold.

\begin{tabular}{lccc}
\hline & Control & Cottonseed meal & Vittelaria paradoxa leaves \\
\hline Cost-benefit ratio & 11.17 & 2.29 & 11.77 \\
Benefit/litre of milk sold & 275.35 & 208.94 & 276.52 \\
(FCFA) & & & \\
\hline
\end{tabular}

\section{Conclusion}

This study shows the positive effect of supplementation on milk yield and confirms its useful utilization even in rainy season (in spite of more perceptible effect in dry season) to maintain a higher milk yield. Dairy production improvement with cows supplemented has a positive impact on calves' growth. Rainy season's supplementation is globally profitable even if this profitability is low for cows supplemented cottonseed meal. Dairy production which is a profitable activity needs a rational use of concentrate and local feed resources rich in protein according to the stage of lactation and the season to be more incomes provider.

\section{ACKNOWLEDGMENTS}

The authors are grateful to the African Network for Agroforestry Education (ANAFE) for funding this study. We are also grateful to the Okpara State farm breeding station director and his assistants in providing animal material and veterinary treatments for the study.

\section{REFERENCES}

AOAC. 1996. Official Methods of Analysis (16th edn). Volume II. Gaithersburg: Maryland, USA.

Chabi Maco Y. 1992. Etude de quelques paramètres de productivité de la race bovine Borgou au Bénin. Thèse d'Ingénieur Agronome, FSA-UNB, Cotonou, p.134.

FAO. 2009. FAO Statistical Yearbook 2009. FAO: Rome.
Faye B, Alary V. 2001. Les enjeux des productions animales dans les pays du Sud. INRA Prod. Anim., 14: 3-13.

Harris BJr, Adams AL, Van Horn HH. 1994. Mineral Needs of Dairy Cattle. Institute of Food and Agricultural Science, University of Florida, Circular No. 468.

Idrissou N-D. 2004. Amélioration intégrée de la production laitière de la vache Borgou au Bénin. Mémoire de DESS, ULgFusagx, Gembloux, p.43.

Kané M. 1996. Supplémentation de la paille de riz avec le tourteau de coton dans l'alimentation des vaches laitières : Relation entre l'ingestion cumulée de matière organique digestible et la production animale (lait, viande). Thèse de Doctorat, ISFRA-Bamako, p.94.

MAEP. 2007. Programme de relance des productions animales au Bénin. Ministère de l'Agriculture, de l'Elevage et de la Pêche, Cotonou.

Ogodja JO. 1988. Estimation de la production laitière et de la croissance des veaux de la race bovine Borgou au Bénin. Thèse d'Ingénieur Agronome, FSA-UNB, Cotonou, p.152.

Ogodja JO, Hounsou-Ve G. 1992. Effet de la complémentation en graine de coton sur la production laitière et la croissance des veaux des vaches allaitantes de race Borgou au Bénin. Bull. Anim. Health Prod. Afr., 41: 51-56.

SAS. 1989. User's guide (version 6, 4th Edn) SAS. Inst. Inc.: Cary, NC, USA.

Senou M, Toléba SS, Adandédjan C, Poivey J-P, Ahissou A, Touré FZ, Monsia C. 2008. Increased Milk Yield in Borgou 
Cows in Alternative Feeding Systems. Revue Élev. Méd. vét. Pays trop., 61(2): 109-114.

Yilma Z, Gojjam Y, Shumye M. 2006. Milk production level and calf-rearing system affecting Boran, Ethiopian zebu cattle breed, cow-calf performance. Livestock Research for Rural Development 18(5). http://www.lrrd.org/lrrd18/5/yilm18071.h tm.
Youssao AKI, Koutinhouin GB, Kpodekon TM, Agnandjo H, Toure Z, Ahissou A. 2009. Influence d'une sélection phénotypique sur les performances de croissance et les caractères de développements musculaire et squelettique de jeunes bovins de race Borgou à la Ferme d'Elevage de l'Okpara (Bénin). Ann. Méd. Vét., 153: 105-111. 